\title{
Crop-Cattle Integrated Farming System: An Alternative of Climatic Change Mitigation
}

\author{
Munandar*, F. Gustiar, Yakup, R. Hayati, \& A. I. Munawar \\ Faculty of Agriculture, Sriwijaya University \\ Jalan Raya Palembang-Prabumulih Km. 32, Ogan Ilir 30662, Sumatera Selatan, Indonesia \\ (Received 22-09-2014; Reviewed 24-11-2014; Accepted 03-06-2015)
}

\begin{abstract}
An integrated farming system is one of the alternatives for climatic change mitigation. This paper reports the application of corn-cattle based integrated farming system in Agrotechno Park Center of Palembang, and discusses its impact on $\mathrm{CO}_{2}$ fixation and the reduction of methane emissions. The study was based on the data of the first $6 \mathrm{yr}$ from 2003 until 2009. The $\mathrm{CO}_{2}$ fixed in the soil and plants was determined based on the content of organic $C$ which was multiplied by the index of 3.67. The methane gas produced by Balinese cattle and its dung was observed and modified into feed rations. The results showed that soil organic C increased from 40.80 tons $C /$ ha in the $1^{\text {st }} \mathrm{yr}$ to 66.40 tons $\mathrm{C} / \mathrm{ha}$ in the $6^{\text {th }} \mathrm{yr}$. In addition, there was organic $\mathrm{C}$ fixation equivalent to 93.95 tons of $\mathrm{CO}_{2}$ e. Corn biomass increased from 6.67 tons/ha to 18.66 tons/ha, equivalent to an increase in the fixation of atmospheric $\mathrm{CO}_{2} \mathrm{e}$ as much as 19.80 tons $\mathrm{CO}_{2} \mathrm{e} / \mathrm{ha}$. The supplementation of $60 \%-80 \%$ grass fodder with concentrate lowered the concentration of methane gas in cattle breathing by $28.7 \%$, from $617 \mathrm{ppm}$ to $440 \mathrm{ppm}$, while the methane emissions from cattle manure decreased by $31 \%$, from $1367 \mathrm{~mL} / \mathrm{head} / \mathrm{d}$ to $943 \mathrm{~mL} / \mathrm{head} / \mathrm{d}$. Installing a bio digester that generates biogas served to accommodate methane gas emissions from cattle dung and used it for bioenergy. Composting reduced the formation of methane gas from cattle manure through a regular process of turning over that gives aeration and forms aerobic condition in the heap of cattle dung. Recycling produces a variety of organic products that store carbon for a longer period of time and slowed the conversion of organic $\mathrm{C}$ into $\mathrm{CO}_{2}$. This study showed that the diverse activities of an integrated crop-cattle farming could be an alternative solution to climatic change mitigation.
\end{abstract}

Key words: integrated farming, mitigation, organic $C$, methane, recycling

\section{ABSTRAK}

Sistem pertanian terpadu merupakan salah satu alternatif untuk mitigasi perubahan iklim. Makalah ini melaporkan kajian penerapan sistem pertanian terpadu berbasis tanaman jagung-ternak sapi di Balai Agrotechnopark Palembang, dan membahas pengaruhnya pada penambatan $\mathrm{CO} 2$ dan penurunan emisi gas metana. Kajian berdasarkan data 6 tahun pertama sejak tahun 2003 sampai 2009. $\mathrm{CO} 2$ tertambat dalam tanah dan tanaman ditentukan berdasarkan kandungan C-organik dan dikalikan dengan indeks 3,67. Produksi gas metana dari ternak sapi dan kotoran sapi diamati pada sapi Bali yang dimodifikasi ransum pakannya. Hasil kajian menunjukkan bahwa C-organik tanah meningkat dari 40,80 ton C/ha pada tahun pertama menjadi 66,40 ton C/ha pada tahun ke-6, terjadi penambatan C-organik yang setara dengan 93,95 ton $\mathrm{CO}_{2}$ e. Biomassa jagung meningkat dari 6,67 ton/ha menjadi 18,66 ton/ha, setara dengan peningkatan penambatan $\mathrm{CO}_{2} \mathrm{e}$ atmosfer sebanyak 19,80 ton $\mathrm{CO}_{2} \mathrm{e} / \mathrm{ha}$. Suplementasi $60 \%$ $80 \%$ pakan rumput dengan pakan konsentrat menurunkan konsentrasi gas metana dalam pernapasan sapi dari $617 \mathrm{ppm}$ menjadi $440 \mathrm{ppm}$, menurun 28,7\%; sedangkan emisi gas metana dari kotoran sapi menurun dari $1367 \mathrm{ml} / \mathrm{ekor} / \mathrm{hari}$ menjadi $943 \mathrm{ml} / \mathrm{ekor} / \mathrm{hari}$, menurun 31\%. Instalasi bio digester yang menghasilkan biogas berfungsi menampung emisi gas metana dari kotoran sapi dan memanfaatkannya untuk bioenergi. Pengomposan mengurangi terbentuknya gas metana dari kotoran sapi melalui proses pembalikan secara teratur yang memberi aerasi dan membentuk kondisi aerobik dalam timbunan kotoran ternak sapi. Daur ulang menghasilkan berbagai produk organik yang menyimpan karbon lebih lama dan memperlambat konversi C-organik menjadi gas $\mathrm{CO}_{2}$. Kajian ini menunjukkan bahwa beragam kegiatan pertanian terpadu tanaman-ternak dapat menjadi alternatif mitigasi dampak perubahan iklim.

Kata kunci: pertanian terpadu, mitigasi C-organik, metana, daur ulang

*Corresponding author:

E-mail: munandar mun@ymail.com 


\section{INTRODUCTION}

Global climatic change is unavoidable and has a serious impact on national food security. In addition to receiving the impact of global climatic change, the agricultural sector contributes to the emissions of the three principal greenhouse gases, namely carbon dioxide $\left(\mathrm{CO}_{2}\right)$, methane $\left(\mathrm{CH}_{4}\right)$ and nitrous oxide $\left(\mathrm{N}_{2} \mathrm{O}\right)$. The total national emissions of greenhouse gases in 2005 reached $1792 \mathrm{Gt} \mathrm{CO}_{2} \mathrm{e}, 5 \%$ of which or $80.179 \mathrm{Gt} \mathrm{CO} 2 \mathrm{e}$ came from the agricultural sector emissions. The main sources of greenhouse gas emissions of the agricultural sector come from rice fields, soil $\mathrm{N}_{2} \mathrm{O}$, and livestock, with the percentage of $46.2 \%, 28.1 \%$, and $19.2 \%$ respectively (Balingtan, 2014).

The agricultural sector challenge related to the climatic change issue is making a strategic approach of mitigation through a remarkable development of agricultural technology which at the same time reduces greenhouse gas emissions from the agricultural sector. Mitigation is an effort to reduce the risk of climatic change by increasing the absorption of greenhouse gases from various sources of emissions. The agricultural sector can play a role in absorbing $\mathrm{CO}_{2}$ in the atmosphere through the process of photosynthesis which absorbs atmospheric carbon and accumulates it in plant biomass and through the accumulation of carbon under the soil surface in the form of soil organic matters and roots. The potential reduction in global emissions of greenhouse gases through the agricultural mitigation action in 2030 was predicted to reach 5.5-6.0 Gt $\mathrm{CO}_{2} \mathrm{e} /$ yr, mostly (89\%) through the potential carbon fixation in the soil. Mitigation action in the agricultural sector in Indonesia started from 2008, and in 2013 there was a success report in reducing greenhouse gas emissions by 12.73 million tons CO2e (Balingtan, 2014).

One alternative of the agricultural mitigation technology is through a system which combines crops and livestock. The characteristics of integrated agricultural technology related to greenhouse gas mitigation are the synergy of waste recycling, the return of organic waste to the land, and the management of livestock waste through composting and biodigester installation to reduce methane emissions (Meggyes \& Nagy 2012; Widihati et al., 2013). A crop-cattle farming integration system has been carried out by rural farmers in Indonesia (Soedjana, 2004; Haryanto, 2009), and in some countries in Africa (Lal, 2001; Ugwumba, 2010) and in Asia (Gill et al., 2009 . Kumar et al., 2012; Murthy et al., 2013; Dash et al., 2015). Studies on this farming system have been widely reported, particularly those that address economic as well as ecological aspects. However, the studies that examine an integrated farming system as an alternative technology which can mitigate greenhouse gases in Indonesia are still not widely reported. This paper reports the study results of the application of corn crop-cattle based integrated farming system in Agrotechno Park (ATP) Center of Palembang and discusses its impact on carbon fixation in the soil and corn crop, and an alternative technology to reduce methane emissions from livestock activities.

\section{MATERIALS AND METHODS}

The study of the integrated farming application was conducted in the AgroTechno Park (ATP) Center of Palembang, Ministry of Research and Technology, North Inderalaya, Ogan Ilir, South Sumatra (20 m asl.) starting from 2003 to 2009. The installation consisted of such components as corn planting, cattle and poultry farming, silage, compost and biogas, mushroom cultivation, worms, horticultural crops, and fish on the marginal land of ex-coconut plantation. Before corn planting was carried out, first of all the land was fertilized by using cattle manure compost as much as 5 tons/ha. The corn straw residues on the land were left to dry. Instead of being burned, the dry corn straws were then crushed by a tractor during the land preparation stage. Corn was planted with a spacing of $65 \times 20 \mathrm{~cm}$ and given a basic fertilizer of ZA $100 \mathrm{~kg} / \mathrm{ha}$, SP $36100 \mathrm{~kg} / \mathrm{ha}$ and $\mathrm{KCl}$ $50 \mathrm{~kg} / \mathrm{ha}$, and it was followed up by the urea application of $250 \mathrm{~kg} / \mathrm{ha}$. The soil samples at the beginning of the study and during the first 6 yr of the study which were taken from several locations were composited and analyzed in the Laboratory of Soil Department of Agriculture Faculty, Sriwijaya University. Farmer's scale biodigester installation was built to utilize cow dung for producing biogas. Biodigester installation consisteds of a fixed dome type biogas tank made of fiber glass with volume of $4 \mathrm{~m}^{3}$. Biodigester wasis designed for 8 cows that produce dung of $7 \mathrm{~kg} / \mathrm{d} / \mathrm{head}$. Biogas produced in biodigester was flowed through the PVC pipe to a $1 \mathrm{~m} 3$ plastic tubes which was connected with a stove for cooking of a household farming family.

Corn biomass was the sum of the weights of corn cob, seedless tuber, straw, and roots. In the first year, the corn samples were taken randomly at several sites to measure the weight of cobs, straw and roots. The corn grains were removed from the cob in order to obtain the grains and the seedless tuber. Then each component of the biomass was measured, weighed and compared. From year 2 to year 6, the weight of each biomass component was determined based on the grains harvested every year. Furthermore, based on the analysis result of the content of soil organic C in the laboratory, C percentage of the soil multiplied by the soil weight $\left(2.10^{6}\right.$ $\mathrm{kg} / \mathrm{ha}$ ) was the weight of soil C per hectare. The organic $\mathrm{C}$ content of the plant was $45 \%$ of the plant biomass. The fixation of $\mathrm{CO}_{2}$ in the soil and plant was based on a weight conversion of 1 ton of organic $C$, which is equivalent to 3,667 tons of $\mathrm{CO}_{2}$ (Jarecki \& Lal, 2003).

The experiment on the potential production of biogas and methane from cattle dung were performed on five groups of Balinese cattle, each consisted of five cattle, which were kept in separate stalls for $30 \mathrm{~d}$. The dung produced was collected, weighed, and averaged. The biogas from the cattle dung was measured by placing $2.5 \mathrm{~kg}$ dung into a mini bio digester, which was left for $30 \mathrm{~d}$. The cumulative volume of biogas produced was measured at the end of the experiment. The volume of methane in biogas was measured by using Portable Gas Monitor, type Odalog 7000. Measurement of methane gas from cow's digestive tract was done by using a facemask method (Purnomoadi et al., 2010). 
Funnel-shaped mask made of $2 \mathrm{~mm}$ thick aluminum plate, coated with a cloth, was tied around the cow's mouth. Mask was attached to the cow's mouth by tying it to the neck and horns. Methane gas concentration was measured by flowing gas through a plastic hose to a portable gas monitor (Odalog 7000). Gas measurement was carried out during the period of $10 \mathrm{~min}$ and the concentration of methane gas was recorded once every 60 s. Measurements were performed three times, which in the morning, at noon and in the evening. Then, the potential volume of biogas and methane from each cattle was calculated by multiplying the dung production per cattle per day with the volume of biogas and methane produced from the experimental bio digester.

\section{RESULTS AND DISCUSSION}

\section{Installation of Integrated Farming System}

An integrated farming system (Figure 1) is an agricultural system that combines such elements as crops, livestock and fish in such a way that synergize with each other to create biological recycles, where the output of one component becomes the input for another component with a high complementary effect (Gill et al., 2009). Corn grains are processed into the feeds of poultry, cattle and fish. Straw residues are dried or fermented into silage for cattle feed. Seedless cobs are minced and used as a mixture of the feeds of cattle, poultry and fish, or as mushroom cultivation media. Cattle and poultry raisings produce meat, milk and eggs. Cattle also produce manure which is utilized as worm culture media and fish feed. Most livestock manure is collected in a bio digester to produce biogas for bioenergy that can be used for cooking and lighting. Worm culture produces worm flour for medicine, fish feed, and vermicompost. All the final waste is processed into compost which is to be returned to the soil as fertilizer for crops.

The cycles of the integrated agricultural farming based on the harvest times can be distinguished into a long-term farming cycle, i.e. cattle farming, a mediumterm farming cycle i.e. corn and fish farming, and daily farming such as vegetable and poultry farming that produces eggs. As a result, economically, farmers get more income sources. Integrated farming systems were reported by many researchers to be able to overcome the constraints of small-sized farm land and the problems of agricultural land conversion (Kumar et al., 2012; Dash et al., 2015). In addition, integrated farming systems could deal effectively with the negative impacts of climatic change, the risk of harvest failure due to pests and diseases, and the fluctuations of selling prices (Lal, 2001; Soedjana, 2004; Niggol. 2010). Next, integrated farming systems could not only generate more profits and increase the welfare of farmer families, but also improve ecology and biodiversity (Hilimire, 2011; Liswati, 2012). Finally, integrated farming systems could support the provision of organic fertilizers, improve efficient use of chemical fertilizers, and increase agricultural productivity as well as meet the needs of the national meat pro-

Table 1. The impact of the application of integrated livestock farming on the soil organic content and $\mathrm{CO}_{2}$ retained in the soil

\begin{tabular}{|c|c|c|c|c|c|}
\hline \multirow{2}{*}{ Year } & \multirow{2}{*}{$\begin{array}{l}\text { Compost } \\
\text { (ton/ha) }\end{array}$} & \multirow{2}{*}{$\begin{array}{l}\text { Plant } \\
\text { residue }\end{array}$} & \multicolumn{2}{|c|}{ C organic of soil } & \multirow{2}{*}{$\begin{array}{c}\text { Equivalent } \\
\mathrm{CO}_{2} \mathrm{e} \\
\text { ton } / \mathrm{ha}^{* *}\end{array}$} \\
\hline & & & $\%$ & ton/ha* & \\
\hline 1 & 5 & 3.17 & 2.04 & 40.8 & 149.61 \\
\hline 2 & 5 & 4.81 & 3.17 & 63.4 & 232.48 \\
\hline 3 & 5 & 5.31 & 3.36 & 67.2 & 264.42 \\
\hline 4 & 5 & 7.84 & 3.68 & 73.6 & 269.89 \\
\hline 5 & 5 & 8.73 & 4.19 & 83.8 & 307.29 \\
\hline 6 & 5 & 8.96 & 3.32 & 66.4 & 243.48 \\
\hline $\begin{array}{l}\text { Total } \\
\text { application }\end{array}$ & 30 & 38.82 & & & \\
\hline $\begin{array}{l}\text { Increase rate/ } \\
\text { year }\end{array}$ & & & 0.21 & 5.12 & 15.64 \\
\hline
\end{tabular}

Note: * \% C organic $x$ soil weight $/$ ha $(2.106 \mathrm{~kg}) ;{ }^{* *}$ Conversion of 1 ton carbon equivalent with 3.667 ton $\mathrm{CO}_{2}$.

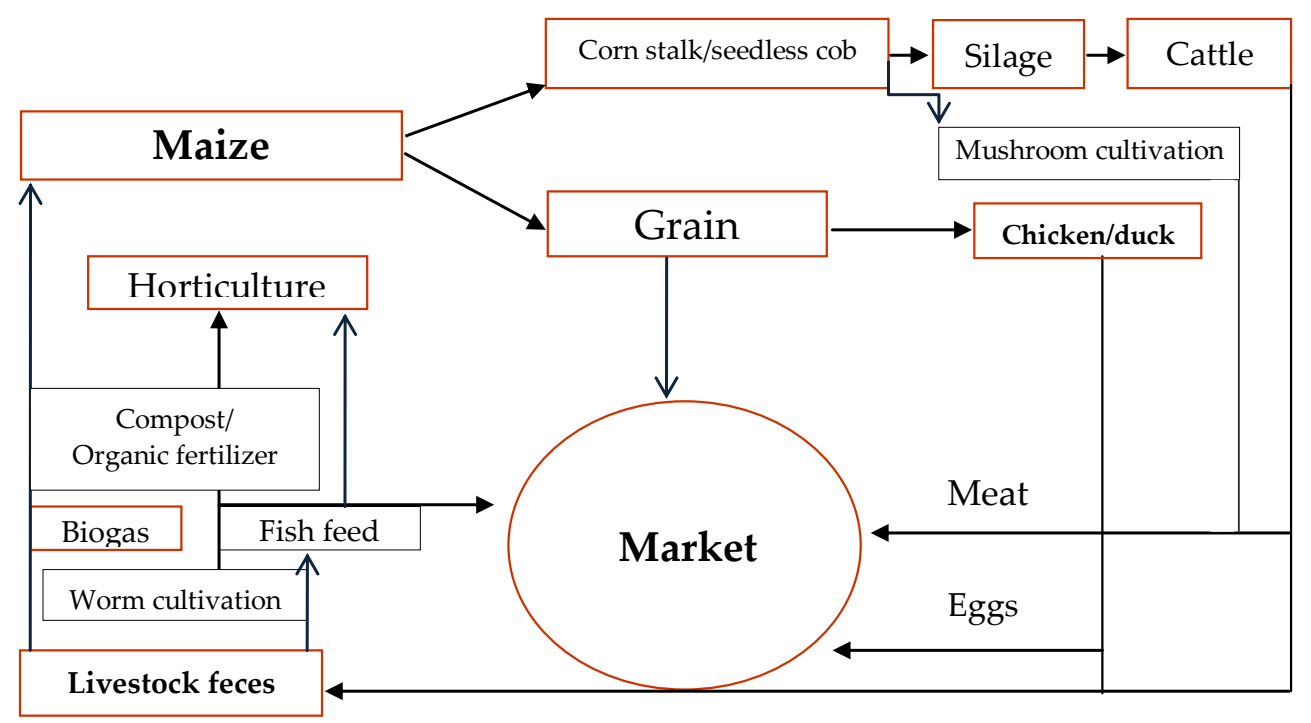

Figure 1. Integrated farming of livestock-maize system at Agrotechno Park (ATP) Center of Palembang 
gram (Kusnadi, 2008; Haryanto, 2009; Meggyes \& Nagy, 2012).

\section{Fixing $\mathrm{CO}_{2}$ in Soil Organic Carbon}

The application of compost and crop residues for 6 yr could increase the content of organic carbon in the soil (Table 1). For $6 \mathrm{yr}, 30$ tons of organic compost fertilizer and 38.32 tons of crop residues such as straw and roots of corn plants were applied to every single hectare of land. The effects of the application showed that the organic carbon content in the first year, which was $2.04 \%$, or equivalent to 40.80 tons $\mathrm{C} / \mathrm{ha}$, increased to $4.19 \%$, or equivalent to 83.80 tons/ha in the fifth year, and then decreased to $3.32 \%$, or equivalent to 66.40 tons $\mathrm{C} /$ ha in the sixth year. The average annual increase of $\mathrm{C}$ in the soil was $0.21 \%$, or equivalent to 5.12 tons $\mathrm{C} / \mathrm{ha} / \mathrm{yr}$ during the first $6 \mathrm{yr}$. If converted to the equivalence of $\mathrm{CO}_{2}$ fixed in the soil, at the beginning it was 149.61 tons $\mathrm{CO}_{2} /$ ha and increased to 243.48 tons $\mathrm{C} /$ ha, or an increase of $\mathrm{CO}_{2}$ fixation in the soil as much as 15.64 tons/ha/yr.

The application of this system had a positive impact on soil fertility components (Table 2). An initial analysis showed that the soil contained low acidic $\mathrm{pH}$, $\mathrm{N}, \mathrm{P}, \mathrm{K}$, and $\mathrm{Ca}$. The soil texture was characterized by high sand content (66.12\%), low clay (18.84\%), and low dust $(14.98 \%)$. The soil $\mathrm{pH}$ increased from 4.9 to 5.96 in the sixth year of application. The content of $\mathrm{N}$ and $\mathrm{K}$ was relatively stable at a moderate level, and the content of P-Bray and Ca increased in the fifth year of application but declined in the sixth year.

Carbon storage in the form of soil organic $\mathrm{C}$ is the transfer process of $\mathrm{CO}_{2}$ from the atmosphere to the soil through the return of crop residues and organic fertilizers to agricultural land, which in turn will fix the atmospheric $\mathrm{CO}_{2}$ in the soil which does not immediately release it back into the atmosphere as $\mathrm{CO}_{2}$ gas. During the 6 yr study, 68.82 tons of organic fertilizer was applied, comprising 30 tons derived from the application of compost and 38.82 tons from crop residues. These applications had an impact on the organic carbon content in the soil. Compost and crop residues contained 40\%-60\% carbon (Jarecki \& Lal, 2003); therefore, the application of the two materials would not only increase the carbon content in the soil, but also indirectly fix $\mathrm{CO}_{2}$ in the soil. In the 6th year, from a total of 68.82 tons of organic fertilizer, or equal to 40.92 tons of organic carbon provision applied to the soil, 25.6 tons of carbon, or equal to $62.6 \%$

Table 2. The impact of integrated livestock farming on the soil fertility parameters

\begin{tabular}{cccccc}
\hline Year & pH soil & $\begin{array}{c}\text { Soil N } \\
\text { content }(\%)\end{array}$ & $\begin{array}{c}\text { P Bray of } \\
\text { soil }(\mathrm{ppm})\end{array}$ & $\begin{array}{c}\mathrm{K} \mathrm{dd} \\
(\mathrm{Cmol} / \mathrm{kg})\end{array}$ & $\begin{array}{c}\mathrm{Ca} \mathrm{dd} \\
(\mathrm{Cmol} / \mathrm{kg})\end{array}$ \\
\hline 1 & 4.90 & 0.27 & 6.89 & 0.31 & 0.42 \\
2 & 4.84 & 0.23 & 3.75 & 0.32 & 0.70 \\
3 & 5.52 & 0.39 & 25.10 & 0.36 & 0.62 \\
4 & 5.96 & 0.21 & 57.75 & 0.26 & 0.55 \\
5 & 5.35 & 0.23 & 91.10 & 0.79 & 1.14 \\
6 & 5.80 & 0.29 & 40.35 & 0.19 & 0.75 \\
\hline
\end{tabular}

carbon was fixed in the soil. At the beginning, the carbon content of the soil was quite high, namely 40.80 tons/ ha. Then, in the $6 \mathrm{yr}$ period, it increased to 66.40 tons $\mathrm{C} / \mathrm{ha}$, or an average annual increase of 5.12 tons/yr for each organic fertilizer application of 11.47 tons/ha/yr to the soil. The fixation level of soil organic $C$ in this study was relatively high when compared with the research conducted by Lal (2001), which reported an increase in soil carbon from 13.1 tons/ha to 15.4 tons/ha by applying 30 tons manure/ha. Meanwhile, Brown et al. (2007), reported that $24.3 \%$ fixation of soil organic carbon was as a result of the application of 64.5 tons of carbon/ha of urban waste compost.

This study also showed that the increase in organic $\mathrm{C}$ as a result of the application of organic manure compost and crop residues had a positive impact on soil fertility parameters, the percentage of soil organic C which increased from $2.04 \%$ to $3.17 \%$ in the second year of application, and subsequently leveled off at levels above $3 \%$. In addition, the increase was also occurred in soil $\mathrm{pH}$ and the content of $\mathrm{P}$ and $\mathrm{Ca}$, indicating that crop residues and animal wastes which are often regarded as wastes of lower economic value, if applied to the land, will be able to restore soil organic $C$ and serve as an effective nutrient source replacing chemical fertilizers (Naderi \& Ghadiri, 2010; Ugwumba, 2010). The agricultural system that returns crop residues to the land will increase organic $C$ in the soil, since the destroyed crop residues during the tillage serve as precursor to the formation of soil organic matters, the main source of stored $\mathrm{C}$ in the soil, the source for microbes, the soil fauna, and the food source for earthworms (Jarecki \& Lal, 2003; Govaerts et al., 2009). The utilization of organic fertilizer and crop residues will make degraded marginal land fertile and productive that can produce food and meat, ultimately increasing organic carbon fixation in the soil (Russelle et al., 2007; Hilimire, 2011).

The real effect of the increase in organic $C$ is the increase in the availability of nutrients and the slow release of them, contributing to the supply of $\mathrm{N}, \mathrm{P}$, and micronutrients and the improvement of the cation exchange capacity (CEC) of the soil (Jarecki et al., 2005). The study results are consistent with those reported by Su et al. (2006), which informed that the application of organic fertilizer for $23 \mathrm{yr}$ would increase soil organic C content from 12.1 tons/ha to 15.46 tons/ha, while the total content of soil $\mathrm{N}$ increased from $0.076 \mathrm{~g} / \mathrm{kg}$ to 1.28 $\mathrm{g} / \mathrm{kg}$. Furthermore, Franzluebbers (2005) reviewed various studies on the benefits of long-term applications of organic fertilizers to the soil fertility and organic carbon accumulation in the soil. An 18-yr study in Kenya showed that the use of 10 tons organic fertilizer/yr could increase 0.17 tons $\mathrm{C} / \mathrm{ha} /$ year, and nearly $9 \%$ of the organic $C$ fertilizer was fixed in the soil. In Nigeria, the use of 5 tons organic fertilizer/ha/yr increased 0.21 tons $\mathrm{C}$ ha/yr and the total content of $\mathrm{P}$ increased by $21 \mathrm{~kg} / \mathrm{ha} /$ yr. A study in India for $30 \mathrm{yr}$ involving the use of 10 tons organic fertilizer/ha/yr showed that the soil organic C increased from $3.3 \mathrm{~g} / \mathrm{kg}$ to $3.9 \mathrm{~g} / \mathrm{kg}$, and the total content of soil $\mathrm{N}$ increased from $361 \mathrm{mg} / \mathrm{kg}$ to $422 \mathrm{mg} / \mathrm{kg}$. 
Table 3. The impact of integrated livestock farming on biomassa and gas $\mathrm{CO}_{2}$ sequestrated in maize plant (ton/ha)

\begin{tabular}{|c|c|c|c|c|c|c|c|}
\hline \multirow{2}{*}{ Year } & \multicolumn{5}{|c|}{ Biomass production } & \multirow{2}{*}{$C$ in biomass* } & \multirow{2}{*}{$\begin{array}{l}\text { Equivalent } \\
\mathrm{CO}_{2} \mathrm{e}^{* *}\end{array}$} \\
\hline & Grain & Cob & Straw & Root & Total & & \\
\hline 1 & 2.10 & 1.40 & 2.50 & 0.67 & 6.67 & 3.00 & 11.02 \\
\hline 2 & 3.20 & 2.10 & 3.80 & 1.01 & 10.11 & 4.55 & 16.70 \\
\hline 3 & 3.50 & 2.30 & 4.20 & 1.11 & 11.11 & 5.00 & 18.35 \\
\hline 4 & 5.20 & 3.40 & 6.20 & 1.64 & 16.44 & 7.40 & 27.15 \\
\hline 5 & 5.80 & 3.80 & 6.90 & 1.83 & 18.33 & 8.25 & 30.27 \\
\hline 6 & 5.90 & 3.80 & 7.10 & 1.86 & 18.66 & 8.40 & 30.82 \\
\hline Average & 4.28 & 2.80 & 5.12 & 1.35 & 13.55 & 6.10 & 22.39 \\
\hline Increase/year & 0.76 & 0.56 & 1.02 & 0.27 & 2.71 & 1.08 & 3.96 \\
\hline
\end{tabular}

Note: ${ }^{*} \mathrm{C}$ Content in biomass $=45 \%$ (Jarecki \& Lal, 2003); ${ }^{* *}$ Conversion 1 ton carbon equivalent with 3.667 ton $\mathrm{CO}_{2}$.

\section{Integrated Farming System Spurs the Fixation of Atmospheric $\mathrm{CO}_{2}$ by Plants}

The fixation of $\mathrm{CO}_{2}$ from the atmosphere through photosynthesis process produces a variety of biomolecules that are stored in the biomass of various plant organs. The increased content of organic C (Table 1) and soil fertility (Table 2) had an impact on seed production and total plant biomass. The production of corn grains increased linearly from 2.1 tons/ha in the first year to 5.9 tons/ha in the sixth year (Table 3). The total biomass increased from 6.67 tons/ha to 18.66 tons/ha. The increased biomass for 6 yr integrated agricultural application was equivalent to the increase of carbon content in plants from 3.00 tons/ha to 8.40 tons/ha in the sixth year. When converted into the amount of fixed atmospheric $\mathrm{CO}_{2}$ in plants, there was an increase of $\mathrm{CO}_{2}$ absorption from 11.02 tons $\mathrm{CO}_{2} / \mathrm{ha}$ at the beginning to 30.82 tons $\mathrm{CO}_{2} / \mathrm{ha}$ at the end of the sixth year. The total production of plant biomass and $\mathrm{CO}_{2}$ absorption by corn plants increased every year on the average of 2.71 tons/ha/yr and 3.96 tons $\mathrm{CO}_{2} / \mathrm{ha} / \mathrm{yr}$ respectively.

The abundant $\mathrm{CO}_{2}$ gas in the atmosphere which reaches 380 ppm can serve as a fertilizer that can increase the rate of photosynthesis and plant growth (Adam et al., 1998). The process of $\mathrm{CO}_{2}$ absorption during photosynthesis produces carbohydrates that are then stored in plant biomass. Biomass consists of fiber, carbohydrates, and other related components that contain carbon. This study used hybrid corn plants, and the biomass was divided into such components as grain $(31.6 \%)$, seedless cob $(20.66 \%)$, straw $(37.75 \%)$ and roots $(10 \%)$. Seeds, seedless cobs, and straw biomass are on the soil surface while the roots under the soil surface are left unharvest. Seeds will be consumed as human food products and animal feed which in the process of digestion and respiration will release $\mathrm{CO}_{2}$ gas and impurities, while straw and roots are left in the soil as crop residues which will be destroyed during land cultivation and will serve as a source of soil organic carbon. Returning dung and crop residues to the land is a $\mathrm{CO}_{2}$ mitigation effort that is proven to increase soil fertility, to fix carbon in the soil, and to improve crop productivity.

An integrated farming system that returns organic fertilizer to the land is a mitigation technique that can reduce greenhouse gas emissions because the carbon is stored in the soil and in the plant biomass. This study showed that during the $6 \mathrm{yr}$ of the application of an integrated farming system, the content of soil organic C increased and had a direct effect on the plant productivity. The more organic matters contained in the soil, the more productive the soil. The soil organic $C$ increased 5.12 tons/ha/yr and the seeds production increased 0.76 tons/ha. In other words, an increase of 1 ton/ha of organic C was followed by an increase of $150 \mathrm{~kg}$ of seed production.

Studies on $\mathrm{CO}_{2}$ fixation through the increase in soil organic carbon had a positive impact on the improvement of the soil quality and agronomic productivity as have been widely reported. Improved soil fertility is a synergy to spur the utilization of $\mathrm{CO}_{2}$ in the atmosphere whose effect is quite dominant as fertilizer on crops (Adam et al., 1998). The use of compost is an alternative technology which is recommended to improve soil quality and agronomic crop yield (Jarecki \& Lal, 2003; Naderi \& Ghadiri, 2010; Hilimire, 2011; Dash et al., 2015). An increase of 1 ton of organic carbon in the soil around the root zone will be able to increase the production of wheat by $20-70 \mathrm{~kg} / \mathrm{ha}$, paddy $0-50 \mathrm{~kg}$ $\mathrm{ha} / \mathrm{ha}$, and corn 30-300 kg/ha (Lal, 2006). According to Franzluebbers (2005), 10 tons organic carbon/ha/ yr could increase canopy biomass of corn crop from 2.7 tons/ha to 6.4 tons/ha, whereas seed production increased from 3.3 tons/ha to 5.3 tons/ha. An integrated farming system applying organic fertilizer and chemical fertilizer creates a very intensive crop cultivation technique as proven in this study to be able to increase the productivity of corn crop from 2.1 tons/ha to 5.9 tons/ha. According to Burney et al. (2010), it is the use of chemical fertilizers that leads to high greenhouse gas emissions, but this spurs the process of photosynthesis which absorbs much $\mathrm{CO}_{2}$ in the atmosphere and stimulates a high rate of growth and crop production in an intensive agricultural cultivation. An agricultural intensification program is a reliable alternative farming technique to reduce the emissions of greenhouse gases.

\section{Reducing Emissions from Livestock Methane Gas}

Based on previous research (Gustiar et al., 2014), methane gas emissions from cattle digestion could be reduced through the supplementation of concentrate to 
substitute grass fodder. The methane concentration in the gas which was released from the mouth and nose of the cattle fed $100 \%$ grass fodder with $0 \%$ concentrate reached 617 ppm, while cattle fed $20 \%$ grass fodder and $80 \%$ concentrate, the concentration of methane gas was $440 \mathrm{ppm}$, a decrease of $28.7 \%$. Furthermore, the production potential for methane in cattle dung decreased from $1367 \mathrm{~mL} / \mathrm{head} / \mathrm{d}$ in cattle fed grass fodder 100\% to $943 \mathrm{~mL} / \mathrm{head} / \mathrm{d}$ in cattle fed $40 \%$ grass fodder and $60 \%$ concentrate, a decline of $31 \%$. Methane gas is one of the greenhouse gases that cause global warming. In ruminants (cattle, buffalo, sheep and goat), methane comes from two sources, namely from the gastrointestinal tract (enteric fermentation) and from the manure. A total of $89 \%$ methane gas as a result of fermentation in the cattle rumen was released through the respiratory tract, and the rest through the anus along the dung. Every day, the gas from the rumen released through respiration reaches 200-500 L/head (Johnson \& Johnson, 1995). The total methane emitted by cattle ranged from $56-71 \mathrm{~kg} /$ head/yr (Johnson \& Johnson, 1995). The total enteric gas production contributed $17 \%-23 \%$ of the total greenhouse gas emissions to the agricultural sector nationally (Bamualim et al., 2008; Balingtan, 2014).

One of the methane gas mitigation strategies through the digestive tract is through the increase in feed efficiency by providing the feed that can be absorbed maximally (Herawati, 2012). The mitigation technology to reduce methane emissions due to the methane fermentation of feed in digestion is to increase the concentrate feed that contains grain starch (Johnson \& Johnson, 1995). The provision of concentrate feed is one of the cattle fattening methods intensively applied to the integrated farming at Agrotechno Park. A decrease in methane gas from the cattle fed concentrate feed supplementation is apparently linked to the high content of carbohydrates and fat in the concentrate feed given. The concentrate feed given in the experiment conducted by Gustiar et al. (2014) composed of 30.5\% rice bran and $31 \%$ palm oil cake. Rice bran contained $19.61 \%$ carbohydrate (Ahmad et al., 2012), and palm oil cake contained 12\%-16.1\% fat (Mustaffa, 1987; Sinurat, 2012). According to Johnson \& Johnson (1995) and Sajati et al. (2012), fermented concentrate feed that contains starch in the rumen will produce propionic acid, whereas fermentation of grass fodder that contains a lot of fiber will produce acetic acid. The production of methane by methanogenic bacteria in the rumen depends on the ratio of propionic acid: acetic acid. If the ratio of propionic acid: acetic acid was 0.5 , the methane produced in the rumen could achieve 0\% GEI (gross energy intake), and if all carbohydrates were fermented to become acetic acid, the methane gas produced could reach 38\% GEI. Meanwhile, the high fat content in the feed stimulates the production of propionic acid which will suppress metanaogenic bacteria and protozoa, organisms in the methane-producing rumen (Johnson \& Johnson, 1995).

This study showed that the mitigation of methane gas from cattle could be done through the supplementation of concentrate feed with high levels of carbohydrates and fats of rice bran and palm kernel cake. Many studies with similar results have been reported (Johnson \& Johnson, 1995; Lovett et al., 2005; Fievez et al., 2005; Ungerfield et al., 2005) that concentrate supplementation with a low level of fiber and nutrient with a high level of fat could lower gas ruminant methane. The decline rate of methane gas was $31 \%$ with concentrate supplementation in this study was relatively similar to a report by Jayanegara et al., (2015), which succeeded in reducing methane gas emissions from cattle by $20 \%$ $27 \%$ in vitro by the addition of a secondary metabolic compound (tannin) as an animal feed additive. Pure tannin compounds were extracted from plant chestnut (Castanea sp.), Mimosa, quebrqcho, sumach, Rhus typhina and Salic alba, and they were rendered into basal rations in form of hay and straw feed (Jayanegara et al., 2009a; Jayanegara et al., 2009b).

Based on the results of cattle dung weighing at Agrotechno Park (Table 4), every cattle excreted between $6.5 \mathrm{~kg}$ and $9.07 \mathrm{~kg}$ or an average of $7,724 \mathrm{~kg} / \mathrm{head} / \mathrm{d}$. If the dung is left open and stacked under anaerobic conditions where there is no oxygen, at a temperature higher than $15{ }^{\circ} \mathrm{C}$, the methanogenic bacteria will ferment and produce methane (Bamualim et al., 2008). The amount of cattle manure mentioned above has the potential of producing methane gas $1.138 \mathrm{~L} / \mathrm{head} / \mathrm{d}$, which will be emitted into the atmosphere as a greenhouse gas.

The release of methane into the atmosphere from cattle manure can be prevented by accommodating cattle manure in a bio digester tank (Bamualim et al., 2008; Meggyes \& Nagy, 2012; Agrahari \& Triwari, 2013; Balingtan, 2014). The bio digester tank will capture the biogas that contains methane, preventing methane gas from going up into the atmosphere. The biogas

Tabel 4. Production of cattle faeces C-N ratio, potential biogas production, and methane from cattle in Agrotechno Park Center of Palembang

\begin{tabular}{cccrrrr}
\hline \multirow{2}{*}{ Farmers group } & \multirow{2}{*}{$\begin{array}{c}\text { Feces } \\
\text { production } \\
(\mathrm{kg} / \mathrm{h} / \mathrm{d})\end{array}$} & $\mathrm{C} / \mathrm{N}$ of feces & \multicolumn{3}{c}{ Biogas } & \multicolumn{3}{c}{ Production potential } \\
\cline { 4 - 7 } & & 30.20 & $\mathrm{~mL} / \mathrm{h} / \mathrm{d}$ & $\mathrm{mL} / \mathrm{kg}$ feces & $\mathrm{mL} / \mathrm{h} / \mathrm{d}$ & $\mathrm{mL} / \mathrm{kg}$ feces \\
\cline { 3 - 7 } & 9.07 & 24.40 & 10.02 & 1.10 & 1361.40 & 150.10 \\
I & 6.50 & 25.60 & 11.23 & 1.73 & 1144.30 & 176.05 \\
II & 7.14 & 26.20 & 9.19 & 1.55 & 943.40 & 132.13 \\
III & 7.28 & 27.80 & 10.66 & 1.26 & 957.90 & 131.58 \\
IV & 8.63 & 26.84 & 10431.40 & 1.38 & 1283.90 & 148.77 \\
V & 7.72 & & & & 1138.18 & 147.73 \\
Average & & &
\end{tabular}


produced by a bio digester is a mixture of several gases (60\% methane and $40 \% \mathrm{CO} 2$ ), which is the result of the decomposition of organic materials by microorganisms in the absence of oxygen (an-aerobic). Biogas can ignite sparks, with an energy of $5.8 \mathrm{kcal} / \mathrm{kg}$ (Papacz, 2011), so it can be used as an alternative energy source that is environmentally friendly and renewable, which is used as fuel for cooking, heating, lighting, generating the propulsion of electrical energy in generator and vehicles (Papacz, 2011; Meggyes \& Nagy, 2012; Widihati et al., 2013; Agrahari \& Triwari. 2013). In the integrated agricultural application at Agrotechno Park Palembang, the biogas from bio digester tube is flowed into the reservoir tube, which is connected to the stove for cooking. One bio digester unit can produce biogas enough for cooking for $4 \mathrm{~h} / \mathrm{d}$, or equivalent to the methane gas production of about 300-500 g/d.

Based on this study, the installation of a biodigester in an integrated farming (Figure 1) which utilizes the methane gas in biogas as bioenergy is an activity that can reduce methane gas emissions into the atmosphere. The potential for methane emissions to the atmosphere that reached $147.73 \mathrm{~mL}$ methane/kg manure (Table 4) can be reduced if the cattle manure is collected in the bio digester and the biogas produced is used for energy. Luske (2010) reported that the mitigation by utilizing cattle manure into biogas reached $112 \mathrm{~kg} \mathrm{CO} \mathrm{e} /$ tons of waste. Cattle manure management by utilizing methane in the form of biogas can reduce $70 \%$ of the methane emissions into the atmosphere, and the rest of the end result is in form of solid waste that can be used as organic fertilizer for plants (Bamualim et al., 2008).

Another alternative mitigation of methane gas from animal waste applied to the integrated farming is by processing cattle manure through composting process (Figure 1). Composting is the decomposition of organic matters into inorganic materials in a controlled treatments under aerobic conditions with the help of micro-organisms, including bacteria, fungi, actinomycetes, worms, and insects. During the composting process, the methane is released by microorganism, but it has been greatly reduced in comparison with the cattle dung which is left stacked in the collection place. The level of methane release during the composting process depends on the amount and type of organic materials, the type of composting, and environmental factors such as humidity and temperature. Turning over and aeration significantly affect methane emissions during composting process (Luske, 2010). An aerobic composting process with controlled treatments--closing the waste pile with plastic sheeting and turning over the compost regularly during the composting process--will not form methane gas but $\mathrm{CO}_{2}$ gas, since the composting process of manure will reduce methane gas emissions into the atmosphere from livestock waste. Every year the Agrotechno Park integrated farming system in Palembang processes approximately 300 tons of manure from 100 cattle and 5,000 chicken and duck into compost which is then returned to the fields as organic fertilizer for corn and horticulture. Aerobic composting is done in a shaded place. Cattle manure waste as the main ingredient for compost making is mixed with plant residues, bran, limestone, and bio starter. The compost materials are stacked to form beds which are covered with tarpaulin, and the aeration is done by stirring and turning over the compost every week for $30 \mathrm{~d}$.

Although this study did not measure the methane emissions during the composting process, various studies showed that composting could reduce methane emissions from cattle manure. Based on this assessment, the potential of methane emissions from cattle manure reached $1.138 \mathrm{~L}$ methane gas/head/d or $147.73 \mathrm{~mL}$ methane gas $/ \mathrm{kg}$ of cattle manure (Table 4). Brown et al. (2008) reported that the potential emissions of methane gas from cattle manure reached $120 \mathrm{~g} / \mathrm{kg}$ manure, and the composting process decreased methane emission by 8.92 $\mathrm{g} / \mathrm{kg}$ manure. According to Luske (2010), the composting process of cattle manure into organic fertilizer lowers methane emissions by $92.5 \%$ from $23,446 \mathrm{~kg} \mathrm{CO}_{2} \mathrm{e} / \mathrm{ha}$ to $1,760 \mathrm{~kg} \mathrm{CO} e / h a$. Meanwhile, a composting process will reduce greenhouse gases $48 \%$ lower than if cattle manure is just left stacked in the collection place, and the composting process of agricultural residues reduces methane emissions into the atmosphere by nearly $100 \%$.

The Indonesian government is committed to reducing global warming by decreasing greenhouse gas emissions by $26 \%$ by 2020 . The national action program of greenhouse gas mitigation is stipulated in Presidential Decree No. 61 of 2011, which states the importance of the widespread use of compost by building UPPO (Organic Fertilizer Processing Unit) and utilizing manure and agricultural wastes for biogas through Batamas program (Biogas of animal origin with the Community) (Balingtan, 2014). The national reduction of greenhouse gas emissions from the agricultural sector in 2013 reached 12.73 million tons of $\mathrm{CO}_{2} \mathrm{e}$, where the UPPO action program and Batamas respectively contributed 2.41 million tons of $\mathrm{CO}_{2} \mathrm{e}(18.9 \%)$ and 2.15 million tons of $\mathrm{CO}_{2} \mathrm{e}(16.9 \%)$ (Balingtan, 2014).

\section{Atmospheric $\mathrm{CO}_{2}$ Storage in Various Organic Products As a Result of Recycling Process}

As shown in Figure 1, the activities of an integrated farming system that recycles agricultural waste from one farming to another farming input is an activity that fixes $\mathrm{CO}_{2}$. Waste recycling activities produce animal feed, silage, fungi, fish, worms, vermicompost, biogas and organic fertilizer. Recycling is a process that fixes $\mathrm{CO}_{2}$ and carbon in the form of organic products for a long period of time. Recycling will spur the transformation of organic waste into carbon in soil organic $\mathrm{C}$ and slows down the conversion of organic carbon into $\mathrm{CO}_{2}$ gas to be released into the atmosphere. An integrated farming system is a complex poly-culture farm comprising the integration and diversification of various crops and livestock farming activities. The conversion from monoculture farming system to poly-culture farming system which is more complex will increase the fixation of C in farmland (Lal, 2003). Each farming technique that increases the absorption of atmospheric $\mathrm{CO}_{2}$ or slows down the release rate of $\mathrm{CO}_{2}$ into the atmosphere will have an impact on carbon fixation from the atmosphere (Adam et al., 1998). An 
integrated farming system also produces more diverse farms that are economically more advantageous than monocultures (Russelle et al., 2007). This system is also a climate-friendly agricultural technology and without waste (zero waste agriculture), does not have a negative effect on the environment, but instead provides added value for livestock activities (Haryanto, 2009), so it is an alternative agricultural mitigation that can reduce greenhouse gas emissions

\section{CONCLUSION}

On the whole, the study showed that the integrated crop-livestock farming was an alternative to mitigate the impact of climatic change through: 1) the return of organic fertilizer and crop residue into the $\mathrm{CO}_{2}$-fixing land in soil organic matters and biomass plants; 2) supplementation of concentrate feed, bio digester installation and cattle dung composting had a role in lowering methane emissions from livestock activities; and 3) the recycle of agricultural waste to produce a variety of organic products that could store carbon for a longer period of time and slowed down the conversion of organic $\mathrm{C}$ into $\mathrm{CO}_{2}$.

\section{ACKNOWLEDGEMENT}

We would like to extend our gratitude to the P2M of Directorate General of Higher Education on Grant of National Strategic Research Funding. Our appreciation also goes to the Rector, Chairman of the Institute for Research and Dean of the Faculty of Agriculture, the University of Sriwijaya, for supporting us to conduct this research. Finally, we also owe gratitude to Agrotechno Park Center of Palembang, Ministry of Research and Technology, for the facilities and cooperation they provided for us.

\section{REFERENCES}

Adam, R. M., B. R. Hurd, S. Lenhart, \& N. Leary. 1998. Effect of global climate change on agriculture: an interpretative review. Climate Res. 11:19-30. http://dx.doi.org/10.3354/ cr011019

Agrahari, R. P. \& G. N. Triwari. 2013. The production of biogas using kitchen waste. The International Journal of Energy Sciences (IJES) 3:408-413. http://dx.doi.org/10.14355/ ijes.2013.0306.05

Ahmad, M., T. A. Qureshi, A. B. Sing, S. Manohar, K. Borana, \& S. R.C halko. 2012. Effect of dietary protein, lipid and carbohydrate content on growth, feed efficiency and carcass composition of Cyprinus carpio communis fingerlings. International Journal of Fisheries and Aquaculture 4:30-40.

Balai Penelitian Lingkungan Pertanian (Balingtan). 2014. Karbon update dan pengurangan emisi gas rumah kaca dari sektor pertanian. Balai Penelitian Lingkungan Pertanian. Badan Penelitian dan Pengembangan Pertanian. Jakarta. 34 Hal.

Bamualim A. M., A. Thalib, Y. N. Anggraeni, \& Mariyono. 2008. Teknologi peternakan sapi potong berwawasan lingkungan. Wartazoa 18:149-156.

Brown, S., C. Kruger, \& S. Subler. 2007. Green house gas balance for composting operation. J. Environ. Qual. 37:13961470. http://dx.doi.org/10.2134/jeq2007.0453

Burney, J. A. Steven, J. Davisc, \& D. B. Lobell. 2010. Green- house gas mitigation by agricultural intensification. PNAS. 107:12052-12057. http://dx.doi.org/10.1073/ pnas.0914216107

Dash, A. K., P. N. Ananth, S. Singh, B. K. Banja, P. R. Sahoo, B. K. Pati, \& P. Jayasankar. 2015. Empirical proof on benefits of integrated farming system in smallholder farms in Odisha. Current Agriculture Research Journal 3:1-12. http:// www.agriculturejournal.org/?p=1261

Fievez, V., F. Dohme, M. Danneels, K. Raes \& D. Demeyer. 2003. Fish oil as potent rumen methane inhibitors and associated effect on rumen fermentation in vitro and in vivo. Anim. Feed Sci. Technol. 104:41-58. http://dx.doi. org/10.1016/S0377-8401(02)00330-9

Franzluebbers, A. J. 2005. Carbon sequestration and land degradation. Soil Tillage Res. 83:120-147. http://dx.doi. org/10.1016/j.still.2005.02.012

Gill, M. S., J. P. Sing, \& K. S. Gangwar. 2009. Integrated farming system and agriculture sustainability. Indian J. Agrono. 54:128-139.

Govaerts, B., N. Verhulst, A. Castellanos-Novarrete, K. D. Sayre, J. Dixon \& L. Dendooven. 2009. Conservation agriculture and soil carbon sequestration: between myth and farmer reality. Crit. Rev. Plant Sci. 28:97-122. http://dx.doi. org/10.1080/07352680902776358.

Gustiar, F., Rujito A. Suwignyo, Suheryanto \& Munandar. 2014. Reduksi gas metana dengan meningkatan komposisi konsentrat dalam pakan ternak sapi. Jurnal Peternakan Sriwijaya 3:14-24.

Haryanto, B. 2009. Inovasi teknologi pakan ternak dalam sistem integrasi tanaman-ternak bebas limbah mendukung upaya peningkatan produksi daging. Pengembangan Inovasi Pertanian 2:163-176.

Herawati, T. 2012. Refleksi sosial dari mitigasi gas rumah kaca pada sektor peternakan di Indonesia, Balai Penelitian Ternak. Wartazoa 22:35-46.

Hilimire, K. 2011. Intergrated crop/livestock agriculture in the United States: a review. J. Sustain. Agr. 35:376-393. http:// dx.doi.org/10.1080/10440046.2011.562042

Jarecki, M. K. \& R. Lal. 2003. Crop management for soil carbon sequestration. Crit. Rev. Plant Sci. 22:471-502. http:// dx.doi.org/10.1080/713608318

Jarecki, M. K., R. Lal \& R. James. 2005. Crop management effect on soil carbon sequestration on selected farmers' field in Northeastern Ohio. Soil and Tillage Research. 81: 265276. http://dx.doi.org/10.1016/j.still.2004.09.013

Jayanegara, A., A. Sofyan, H. P. S. Makkar, \& K. Bekker. 2009a. Kinetika produksi gas, kecernaan bahan organik dan produksi gas metana in vitro hay dan jerami yang disuplementasi hijauan mengandung tanin. Med. Pet. 32:120-129.

Jayanegara, A., H. P. S. Makkar, \& K. Bekker. 2009b. Emisi metana dan fermentasi rumen in vitro ransum hay yang mengandung tanin murni pada konsentrasi rendah. Med. Pet. 32:185-195.

Jayanegara, A., H. P. S. Makkar, \& K. Bekker. 2015. Addition of purified tanin sources and polyethylene glycol treatment on methane emission and rumen fermentation in vitro. Med. Pet. 38:57-63. http://dx.doi.org/10.5398/medpet.2015.38.1.57

Johnson, K. A. \& D. E. Johnson. 1995. Methane emission from cattle. J. Anim. Sci.73:2483-2492.

Kumar, S., N. Subash, S. Shivani, S. S. Singh, \& A. Dey. 2012. Evaluation of different components under integrated farming system (IFS) for small and marginal farmers under semi-humid climatic environment. Exp. Agr. 48:399-413.

Kusnadi, U. 2008. Inovasi teknologi peternakan dalam sistem integrasi tanaman-ternak untuk menunjang swasembada daging sapi. Pengembangan Inovasi Pertanian. 1:189-205.

Lal, R. 2001. Carbon sequestration in dryland ecosystem of West Asia and North Africa. Land Degrad. Dev. 13: 45-49. http:// 
dx.doi.org/10.1002/ldr.477

Lal, R. 2006. Enhancing crop yields in the developing countries through restoration of the soil organic carbon pool in agricultural lands. Land Degrad. Dev. 17: 197-209. http:// dx.doi.org/10.1002/ldr.696

Liswati, L. 2012. Pola pertanian terpadu ternak dan tanaman hortikultura di Kota Pekanbaru. Jurnal Peternakan 9:75-82.

Lovett, D. K., L. J. Stack, S. Luvel, J. Callan, B. Flynn, M. Hawkin. \& F. P. O'Mara. 2005. Manipulating enteric methane emission and animal performance of late-lactation dairy cows through concentrate supplementation at pasture. J. Dairy Sci.88:2836-2842. http://dx.doi. org/10.3168/jds.S0022-0302(05)72964-7

Luske, B. 2010. Reduced green house gas emission due to compost production and compost use in Egypt, Comparing two scenarios. The Louis Bolk Institute, Soil and More International. 30 pp. http://orgprints.org/17480

Meggyes, A. \& V. Nagy. 2012. Biogas and energy production by utilization of different agricultural waste. Acta Polytechnica Hungaria 9:65-80.

Murthy, I. K., M. Gupta, S. Tomar, M. Munsi, R. Tiwari, G. T. Hedge, \& R. H. Ravindranath 2013. Carbon sequestration potential of agroforestry system in India. Journal Earth Sci. and Climate Change. 4:131-137. http://dx.doi. org/10.4172/2157-7617.1000131

Mustaffa, A. B. 1987. Palm kernel cake as a new feed for cattle. Asian Livestock, Vol. XI, No. 5, pp 49-50. FAO/APHCA Publication. Bangkok, Thailand.

Naderi, R. \& H. Ghadiri. 2010. Urban waste compost, manure and nitrogen fertilizer effect on the initial growth of corn (Zea mays L.). Desert. 15:159-165. http://jdesert.ut.ac.ir

Niggol, S.S. 2010. Is an integrated farm more resilient against climate change? A micro-economic analysis of portfolio diversification in African agriculture. Food Policy. 35:32-40. http://dx.doi.org/10.1016/j.foodpol.2009.06.004

Papacz, W. 2011. Biogas as vehicle fuel. Journal of Kones Powertrain and Transport. 18:404-410.

Purnomoadi A., E. Rianto, M. Mulyadi, F. Kurniasari, O. Enishi, \& M. Kurihara. 2010. Effects of supplementing urine treated rice straw with concentrates on productivity and methane emissions of Ongole crossbred cattle. In Sustainable Improvement of Animal Production and Health. Eds. N.E. Odongo, M.Garcia \& G.J. Viljoen. Eds: Animal Production and Health Subprogram. Joint FAO/IAEA Program. FAO of the United Nation. Rome.

Russelle, M. P., M. H. Entz, \& A. J. Franzluebbers. 2007. Reconsidering integrated crop-livestock systems in North America. Agron. J. 99:325-334. http://dx.doi.org/10.2134/ agronj2006.0139

Sajati, G., B. W. H. E. Prasetyo \& Surono. 2012. Pengaruh ekstrusi dan proteksi dengan tanin pada tepung kedelai terhadap produksi gas total dan metan secara in vitro. Animal Agricultural Journal 1:241-256. http://ejournal-s1. undip.ac.id/index.php/aaj.

Sinurat, A. P. 2012. Teknologi pemanfaatan hasil samping industri sawit untuk meningkatkan ketersediaan bahan pakan unggas. Pengembangan Inovasi Pertanian 5:65-78.

Soedjana, T. D. 2004. Sistem usahatani terintegrasi tanaman ternak sebagai respon petani terhadap faktor risiko. Jurnal Litbang Pertanian. 26:82-87.

Su, Y. Z., F. Wang, D. R. Suo, Z. H. Zhang, \& M. W. Du. 2006. Longterm effect of fertilizer and manure application on soil-carbon sequestration and soil fertility under wheatwheat-maize cropping system. Nutr. Cycl. Agroecosystem. 75:285-295.

Ugwumba, C. O. A. 2010. Environmental sustainability and profitability of integrated fish cum crop farming in Anambra state, Nigeria. Agricultural Journal 5:229-233. http:// dx.doi.org/10.3923/aj.2010.229.233

Ungerfield, E. M., S. R. Rust, R. J. Burnett, M. T. Yokoyama \& J. K. Wang. 2005. Effect of two lipid on in vitro ruminal methane production. Anim. Feed Sci. Technol. 119:179-185. http://dx.doi.org/10.1016/j.anifeedsci.2004.12.007

Widihati, I. A. G., I. N. Simpen, \& N. M. Puspawati. 2013. Produksi bioenergy alternatif dalam biodigester mobile melalui pemanfaatan limbah ternak sapi Bali untuk menunjang peternakan berkalanjutan. Udayana Mengabdi 12:84-86. 